\title{
AKOMODASI BUDAYA LOKAL ('URF) DALAM PEMAHAMAN FIKIH ULAMA MUJTAHIDIN
}

\author{
lim Fahimah \\ Pascasarjana IAIN Bengkulu \\ J. Raden Fatah Pagar Dewa Bengkulu \\ Email: fahimah_iim@yahoo.co.id
}

\begin{abstract}
Culture is a set of human knowledge that is used as a guide or to interpret the overall human actions. Culture is also a guideline for people's lives which is believed to be true by the community. As a pattern for action, culture contains a set of knowledge possessed by humans as social beings, whose contents are devices, models of knowledge that are selectively used to understand and interpret the environment faced and to encourage and create necessary actions. Whereas as a pattern of action, culture is what happens in the daily lives of people based on guidelines believed to be true. Furthermore, in order to ground Islam to society so that the concept of Islamic law becomes a handle in interacting, accommodating local culture in Islamic law is a must. Acceptance of $\mathrm{f}$ urf as one of the arguments in establishing Islamic law provides an opportunity for the dynamics of Islamic law. Because many problems are not accommodated in the method of qiyas, istihsan, mashlahah mursalah and others, can be accommodated by 'urf (local culture). Scholars accommodate local culture which in some ways is difficult to deny its need for that culture.
\end{abstract}

Keywords: accommodation, local culture, islamic jurisprudence

\begin{abstract}
Abstrak: Kebudayaan adalah seperangkat pengetahuan manusia yang dijadikan sebagai pedoman atau menginterpretasikan keseluruhan tindakan manusia. Kebudayaan juga pedoman bagi kehidupan masyarakat yang diyakini kebenarannya oleh masyarakat tersebut. Sebagai pola bagi tindakan, kebudayaan berisi seperangkat pengetahuan yang dimiliki oleh manusia sebagai makhluk sosial, yang isinya adalah perangkat-perangkat, model-model pengetahuan yang secara selektif digunakan untuk memahami dan menginterpretasikan lingkungan yang dihadapi dan untuk mendorong dan menciptakan tindakantindakan yang diperlukan. Sedangkan sebagai pola dari tindakan, kebudayaan adalah apa yang terjadi di dalam kehidupan sehari-hari masyarakat yang berdasar pada pedoman yang diyakini kebenarannya. Selanjutnya dalam rangka membumikan Islam pada masyarakat agar konsep hukum Islam menjadi pegangan dalam berinteraksi, maka mengakomodasi budaya lokal dalam hukum Islam adalah suatu keharusan. Diterimanya 'urf sebagai salah satu dalil dalam penetapan hukum Islam memberi peluang bagi dinamisasi hukum Islam. Sebab banyak permasalahan yang tidak tertampung dalam metode qiyas, istihsan, mashlahah mursalah dan yang lainnya, dapat ditampung oleh 'urf (budaya lokal). Ulama mengakomodasi budaya lokal yang dalam beberapa hal sulit dipungkiri kebutuhannya terhadap budaya tersebut.
\end{abstract}

Kata kunci: akomodasi, budaya lokal, fikih

\section{Pendahuluan}

Budaya dipandang sebagai bagian dari kehidupan masyarakat, sehingga tidak memungkinkan bagi sebuah gerakan agama yang membawa nafas rahmatan lil'alamin memberangus sesuatu yang sudah menjadi bagian dari masyarakat.

Kebudayan adalah keseluruhan pengetahuan yang dimiliki manusia selaku makhluk sosial atau pedoman bagi kehidupan manusia yang diyakini kebenarannya oleh masyarakat tertentu. Isinya perangkat-perangkat atau model-model pengetahuan yang secara selektif dapat digunakan untuk memahami dan menginterpretasi lingkungan yang dihadapi serta mendorong dan menciptakan tindakan-tindakan yang diperlukan masyarakatnya sendiri. Interaksi Islam dan budaya lokal adalah sebagai upaya untuk melihat hubungan dinamis antara Islam dengan berbagai nilai dan konsep kehidupan yang dipelihara 
dan diwarisi serta dipandang sebagai pedoman hidup oleh masyarakat terkait. Pedoman hidup dimaksud juga mencakup tradisi yang diwarisi dari generasi ke generasi yang hingga kini fenomenanya masih tampak. Dalam hal ini ulama fikih mempunyai pandangan sendiri dalam memperlakukannya sebagai sumber hukum atau sebagai metododologi dalam pengambilan hukum.

\section{Akomodasi, Budaya Lokal, 'Urf dan Adat}

Akomodasi menurut bahasa ada beberapa arti sebagai berikut:

a. Sesuatu yang disediakan untuk memenuhi kebutuhan, misalnya tempat menginap atau tempat tingggal sementara bagi orang yang bepergian: dia bertugas menyiapkan bagi para tamu yang datang dari luar daerah

b. Bio penyesuaian mata untuk menerima suatu bayangan yang jelas dari objek yang dilihat

c. Antara penyesuaian manusia dalam kesatuan sosial untuk menghindari dan meredakan interaksi ketegangan dan konflik.

d. Penyesuaian sosial dalam interaksi antara pribadi dan kelompok manusia untuk meredakan pertentangan.

e. Kamar atau atau ruang tempat tinggal awak kapal atau penumpanng kapal ${ }^{1}$.

Sedangkan pengertian akomodasi menurut istilah adalah cara menyelesaikan pertentangan antara dua pihak tanpa menghancurkan salah satu pihak, sehingga kepribadian masing-masing pihak tetap terpelihara. Akomodasi memiliki beberapa bentuk, sebagai berikut:

1. Coercion yaitu suatu bentuk akomodasi yang dapat terjadi karena adanya pemaksaan kehendak pihak tertentu kepada pihak lain yang lebih lemah.

2. Kompromi yaitu suatu bentuk akomodasi dimana pihak yang berselisih saling mengurangi tuntutan supaya menemukan

\footnotetext{
${ }^{1}$ Pusat Bahasa Departeman Pendidikan Nasional, Kamus besar Bahasa Indonesia, (Jakarta: Balai Pustaka, 2008), h. 21.
}

sebuah penyelesaian, serta seluruh pihak bersedia untuk memahami dan merasakan keadaan pihak yang lain.

3. Arbitrasi yaitu suatu bentuk akomodasi dimana pihak-pihak yang terlibat dalam perselisihan tidak dapat mencapai kompromi sendiri. Untuk itu, akan diundang pihak ketiga yang tidak memihak/netral untuk mengusahakan penyelesaian pertentangan tersebut. Pihak ketiga di sini dapat pula ditunjuk atau dilaksanakan oleh sebuah badan yang mempunyai wewenang.

4. Mediasi yaitu bentuk akomodasi yang mirip dengan arbitrasi. Tetapi, pihak ke-3 yang bertindak sebagai penengah dan tidak berwenang untuk memberi keputusan penyelesaian terhadap pertikaian pada kedua belah pihak.

5. Konsiliasi yaitu suatu bentuk akomodasi untuk mempertemukan keinginan-keinginan dari pihak-pihak yang berselisih demi tercapainya suatu persetujuan bersama.

6. Toleransi yaitu suatu bentuk akomodasi tanpa adanya kesepakatan yang resmi. Biasanya terjadi karena adanya keinginan-keinginan untuk sebisa mungkin menghindarkan diri dari pertikaian yang dapat merugikan di antara kedua belah pihak.

7. Stalemate yaitu suatu bentuk akomodasi pada saat kelompok yang terlibat pertentangan mempunyai kekuatan seimbang.

8. Ajudikasi yaitu penyelesaian sengketa atau permasalahan melalui jalur hukum atau pengadilan. Akomodasi dilakukan dengan tujuan untuk:

1) Mengurangi pertentangan akibat perbedaan paham.

2) Mencegah meluasnya pertentangan untuk sementarawaktu

3) Mewujudkan kerjasama antara kelompok yang hidup terpisah ${ }^{2}$.

\footnotetext{
${ }^{2}$ http://temukanpengertian.blogspot.com/2013/09/ pengertian-akomodasi.hl, diakses 4 Juni 2018.
} 


\section{Pengertian Budaya Lokal, 'Urf dan 'Adat}

Kata budaya artinya: 1 akal budi, hasil, 2. adat istiadat, 3. sesuatu mengenai kebudayaan yang sudah berkembang (beradab, maju,) 4. Sesuatu yang sudah menjadi kebiasaan yang sudah sukar diubah. ${ }^{3}$ Berbudaya artinya mempunyai pikiran, akal yang sudah maju. Membudaya berarti menjadi kebudayaan atau menjadi kebiasaan yang dianggap wajar. Sedangkan membudayakan berarti: mengajar supaya mempunyai beradab (berbudaya) bisa juga berarti: membiasakan suatu perbuatan yang baik sehingga dianggap sebagai yang berbudaya ${ }^{4}$. Adapun arti lokal adalah: 1 . Ruang yang luas, 2. Terjadi (berlaku, ada, dan sebagainya) di satu tempat, tidak merata, 3. Di satu tempat (pembuatan, produksi, tumbuh, hidup dan sebagainya) setempat. ${ }^{5}$ Budaya lokal berarti berarti budaya setempat.

Kata 'urf secara etimologi berasal dari kata 'arafa, ya' rifu berarti sesuatu yang dikenal ${ }^{6}$, sesuatu yang dipandang baik dan diterima oleh akal sehat ${ }^{7}$. Dalam kamus bahasa Arab (seperti al-Qamus, Lisan al-'Arab, al-Misbah al-Munir) dijelaskan bahwa makna al-'adah dari segi bahasa adalah suatu perilaku yang dilakukan secara berulang-ulang sehingga menjadi kebiasaan, karakter atau culture. Dalam kamus Maurid dikatakan: adat adalah terbiasa melakukan, dan membiasakannya akhirnya menjadi adat baginya ${ }^{8}$. Dalam sebuah syair yang masyhur dikatakan ta awwad shalih alakblaqi, fa inni raitu al-mar'a yaklafu ma ista 'adda (biasakanlah berakhlaq yang terpuji karena aku melihat seorang akan jinak terhadap kebiasaannya). Secara terminologi, pandangan fukaha dan ushuliyyun terhadap al-'adah, yaitu

\footnotetext{
3 Pusat Bahasa Departemen Pendidikan Nasional, Kamus Besar Bahasa Indonesia, (Jakarta: Balai Pustaka, 2008), h. 169.

4 Pusat Bahasa Departemen Pendidikan Nasional, Kamus Besar..., h. 169.

5 Pusat Bahasa Departemen Pendidikan Nasional, Kamus Besar..., h. 680.

6 Amir Syarifuddin, Ushul Fiqh Jilid 2, (Jakarta: Logos, 2001), Cet.ke-2, h. 363.

7 Satria Effendi M. Zein, Ushul Fiqh, (Jakarta: Prenada Media, 2005),Cet.ke-1, h. 153.

${ }^{8}$ Ba'labaki Ruhi, al-Maurid. Qamus 'Arabi Ingglizi, (Beirut: Dar al- ilmi lilmalayin, 1993), h. 742.
}

sesuatu yang telah familiar, menjadi biasa, dalam masyarakat dan melekat sehingga menjadi tradisi. Definisi ini mencakup kebiasaan yang dilakukan oleh perorangan maupun kelompok, apakah perkara (adat) tersebut bersumber dari bersifat natural (alam) seperti perubahan iklim, atau perkara (adat) tersebut dari hawa nafsu seperti memakan harta dengan cara yang batil, melakukan kezaliman, kefasikan, kemaksiatan dan lain-lain.

Sedangkan secara terminologi, sebagaimana dinyatakan Abdul Karim Zaidan, urf berarti: sesuatu yang tidak asing lagi bagi suatu masyarakat karena telah menjadi kebiasaan dan menyatu dengan kehidupan mereka, baik berupa perbuatan atau perkataan'. Abu Zahrah menyatakan urf adalah kebiasaan manusia dalam urusan muamalat dan menegakkan urusan-urusan mereka ${ }^{10}$.

Di antara para ulama, ada yang menyatakan bahwa pengertian urf sama dengan al'adah, keduanya muradif'. Selanjutnya Amir Syarifuddin menyatakan bila diperhatikan kedua kata tersebut dari segi asal penggunaan dan akar katanya, maka terdapat perbedaan antara keduanya. Kata al-'adah berasal dari kata 'ada, ya'udu yang mengandung arti pengulangan (tikrar). Sesuatu dikatakan sebagai ‘adah jika telah dilakukan secara berulang. Namun, tidak ada ukuran dan banyaknya pengulangan sehingga perbuatan tersebut dinyatakan sebagai 'adah. Kata 'urf tidak mengacu pada segi berulang kalinya suatu perbuatan itu dilakukan, tetapi dari segi bahwa perbuatan tersebut sudah sama-sama dikenal dan diakui oleh orang banyak $^{12}$.

Imam al-Syathibi dalam al-Muwafaqat membagi adat ke dalam dua bagian yaitu adat yang bersifat syar ${ }^{i}$ dan adat yang tidak bersifat syar ${ }^{\prime} i$. Adat yang bersifat syar`i dapat diukur dengan

\footnotetext{
${ }^{9}$ Abd al-Karim Zaidan, Al-Wajiz fi Ushul al-Fiqh, (Beirut: Ma'assasah al-Risalah, 1986), h. 252.

${ }^{10}$ Muhammad Abu Zahrah, Ushul al-Fiqh, (Tt: Dar al-Fikr al-'Arabi, 1958), h. 273.

${ }^{11}$ Satria Effendi Zein, Ushul Fiqh, h. 153.

${ }^{12}$ Amir Syarifuddin, Ushul Fiqh, h. 363.
} 
dalil-dalil syar`i secara langsung, mengingat teks-teks syariah memberikan penjelasan secara langsung baik itu bersifat perintah atau larangan, sedangkan adat yang tidak bersifat syar' $i$ lebih dipengaruhi oleh kebutuhan insting dan biologis manusia seperti makan minum, berhubungan dengan istri dan situasi alam seperti perubahan iklim dan lain-lain, atau dengan kata lain adat yang tidak bersifat syar `i adalah yang tidak mendapatkan legitimasi dalil syar'i secara langsung ${ }^{13}$.

Jika kita telusuri sebenarnya tidak ada perbedaan yang prinsip karena pengertian kedua kata tersebut tidak ada perbedaan yang prinsip. Keduanya mempunyai pengertian yang sama yaitu suatu perbuatan yang telah berulang-ulang dilakukan menjadi dikenal dan diakui orang banyak; sebaliknya karena perbuatan tersebut telah dikenal dan diakui orang banyak, maka perbuatan itu dilakukan orang secara berulangulang ${ }^{14}$.

Dari segi kandungan artinya kedua kata tersebut memiliki perbedaan makna. Kata 'adah hanya memandang dari segi pengulangan suatu perbuatan itu dilakukan dan tidak meliputi penilaian segi baik atau buruknya perbuatan tersebut sehingga dapat dinyatakan ia berkonotasi netral. Sedangkan 'urf digunakan dengan memandang segi pengakuan terhadap suatu perbuatan, diketahui dan diterima oleh orang banyak. Dengan demikian, kata 'urf mengandung konotasi baiknya perbuatan tersebut sebagai mana penggunaannya dalam Q.S. al-A'raf[7]: 199. Lain lagi tinjauan Musthafa Syalabi yang membedakan keduanya dari segi ruang lingkup penggunaannya. Kata ‘urf selalu digunakan untuk jamaah atau golongan sedang kata 'adah dapat saja berlaku pada perorangan, sebagian orang di samping pada golongan ${ }^{15}$.

Ketentuan harus sesuatu yang dikenal, diakui dan diterima oleh orang banyak pada 'urf dan

${ }^{13}$ Al-Syathibi, al-Muwafaqat fi Ushul al-Syari ah, (Beirut: Dar al-Márifah, 1994), h. 583.

${ }^{14}$ Al-Syathibi, al-Muwafaqat fi Ushul al-Syari ah, h. 363-364.

${ }^{15}$ Al-Syathibi, al-Muwafaqat fi Ushul al-Syari ah, h. 364-365. 'adah di atas memiliki kemiripan dengan ijma'. Namun, terdapat perbedaan-perbedaan sebagai berikut:

1. Dari segi ruang lingkupnya, ijma' harus diakui dan diterima semua pihak. Ijma tidak terwujud jika terdapat segelintir orang yang tidak setuju atau menolak. Sedangkan 'urf dan 'adah cukup dilakukan atau dikenal oleh sebagian besar orang saja.

2. Ijma' adalah kesepakatan para mujtahid bukan masyarakat pada umumnya berbeda dengan 'urf dan 'adah melibatkan seluruh anggota masyarakat termasuk di antaranya adalah para mujtahid.

3. 'Adah dan 'urf bisa mengalami perubahan karena perubahan situasi dan kondisi masyarakat. Sedang ijma' sebagai sebuah dalil hukum tidak mengalami perubahan ${ }^{16}$.

Selanjutnya dalam makalah ini penulis menggunakan istilah 'urf saja untuk mewakili ’urf dan `adah mengingat keduanya memiliki makna yang hampir sama dan untuk konsistensi dan keseragaman penulisan.

\section{Macam-Macam `Urf}

'Urf itu dapat dilihat dari obyeknya, dari cakupannya, dan dari keabsahannya.

1. Dari sisi obyeknya, ’urf dapat dibagi pada dua macam yaitu:

a. Al-Urf al-Lafzhi adalah kebiasaan masyarakat dalam mempergunakan lafaz atau ungkapan tertentu. Apabila dalam memahami ungkapan perkataan diperlukan arti lain, maka itu bukanlah 'urf.

b. Al-Urf al-Amali, adalah kebiasaan masyarakat yang berkaitan dengan perbuatan.

2. Dari sisi cakupannya, 'Urf terbagi kepada dua bagian, yaitu:

a. Al-'Urf al-'Am yaitu kebiasaan tertentu yang berlaku secara luas di seluruh masyarakat dan di seluruh daerah.

${ }^{16}$ Al-Syathibi, al-Muwafaqat fi Ushul al-Syari ah, h. 365. 
b. Al-'Urf al-Khash, yaitu kebiasaan yang berlaku di daerah dan masyarakat tertentu.

3. Dari sisi keabsahannya dalam pandangan syara. dapat dibagi pada dua bagian yaitu:

a. Al-'Urf al-Shahih adalah kebiasaan yang dilakukan oleh orang-orang yang tidak bertentangan dengan dalil syara', tiada menghalalkan yang haram dan mengharamkan yang halal, juga tidak membatalkan yang wajib.

b. Al-'Urf al-Fasid, yaitu kebiasaan yang dilakukan oleh orang-orang, berlawanan dengan ketentuan syariat, karena membawa kepada menghalalkan yang haram atau membatalkan yang wajib.

\section{Syarat-syarat `Urf}

'Urf yang menjadi tempat kembalinya para mujtahid dalam berijtihad dan berfatwa, dan hakim dalam memutuskan perkara, disyaratkan sebagai berikut:

1. 'Urf tidak bertentangan dengan nash yang qath `i. Karena itu tidak dibenarkan sesuatu yang telah menjadi biasa yang bertentangan dengan nash yang qath $i$.

2. 'Urf harus umum berlaku pada semua peristiwa atau sudah umum berlaku.

3. 'Urf harus berlaku selamanya. Maka tidak dibenarkan urf yang datang kemudian. Oleh sebab itu, orang yang berwakaf harus dibawakan kepada 'urf pada waktu mewakafkan, meskipun bertentangan dengan 'urf yang datang kemudian.

4. Tidak ada dalil yang khusus untuk kasus tersebut dalam Alquran atau hadis.

5. Pemakaiannya tidak mengakibatkan dikesampingkannya nash syariah dan tidak mengakibatkan kemadaratan juga kesempitan.

\section{Landasan Pensyari'atan 'Urf Menjadi Landasan Hukum}

Para Ushuliyun sepakat menolak 'urf fasid untuk dijadikan landasan hukum. Menurut al-
Thayyib Khudari al-Sayyid, guru besar Ushul Fiqh Universitas al-Azhar Kairo, menyatakan bahwa pada prinsipnya mazhab yang empat sepakat menerima adat istiadat sebagai landasan pembentukan hukum. Walaupun dalam jumlah dan rinciannya terdapat perbedaan di antara mereka. Sehingga 'urf dimasukkan dalam dalil hukum yang diperselisihkan oleh para Ushuliyun ${ }^{17}$.

Di antara dalil pensyariatan 'urfadalah:

1. Q.S. al-A`raf[7]: 199

"Jadilah engkau pemaaf dan surublah orang mengerjakan yang makruf, serta berpalinglah dari pada orang-orang yang bodoh".

Kata 'urf dalam ayat di atas oleh Ushuliyun dipahami sebagai sesuatu yang baik dan telah menjadi kebiasaan masyarakat. Maka ayat di atas menjadi landasan untuk mengerjakan sesuatu yang dianggap baik yang menjadi tradisi dalam suatu masyarakat ${ }^{18}$. Pada prinsipnya syariat Islam menerima dan mengakui adat dan tradisi selama tidak bertentangan dengan Alquran dan sunah. Islam tidak serta merta menghapus tradisi dalam masyarakat Arab ketika ia diturunkan. Tradisi yang baik dilestarikan sedang tradisi yang buruk secara bertahap dihapuskan. Sebagi contoh tradisi masyarakat Arab yang dilestarikan adalah praktek bagi hasil dalam perdagangan (mudharabah), jual beli salam yang merupakan kebiasaan masyarakat Madinah, dan jual beli 'araya (jual beli kurma yang masih "basah" yang masih di pohon dengan kurma yang sudah kering) ${ }^{19}$.

2. Hadis nabi saw:

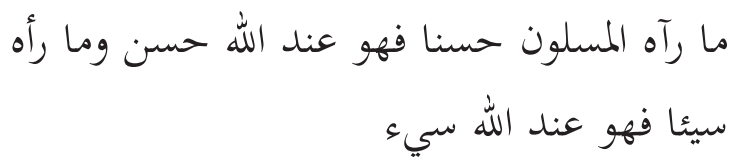

"Segala sesuatu yang dianggap kaum muslimin baik, maka demikian itu di sisi Allah adalah perbuatan yang baik".

\footnotetext{
${ }^{17}$ Satria Effendi M. Zein, Ushul Figh, h. 155.

${ }^{18}$ Satria Effendi M. Zein, Ushul Figh, h. 155-156.

${ }^{19}$ Satria Effendi M. Zein, Ushul Figh, h. 156. Abdul Karim Zaidan, Al-Wajiz fi Ushul..., h. 254-255.
} 
Menurut hadis ini perbuatan yang telah menjadi kebiasaan kaum muslimin yang dipandang baik maka di sisi Allah merupakan perbuatan yang baik. Perbuatan yang menyalahi kebiasaan yang dipandang baik tersebut akan menyebabkan terjadinya kesulitan dan kesempitan dalam hidup mereka. Mazhab Hanafi dan Maliki menyatakan bahwa sesuatu yang ditetapkan berdasarkan 'urf yang shahih setara dengan penetapan dengan dalil syara ${ }^{20}$. Dan hadis Rasulullah saw. tentang kisah Hindun; istri Abu Sufyan yang mengadukan kebakhilan suaminya dalam memberikan nafkah. Rasul bersabda,"khudzi min mali Abi Sufyan ma yakfiki wa waladaki bi al-ma 'ruf." (ambillah dari harta Abi Sufyan sesuai kebutuhan yang pantas untukmu dan anakmu). Menurut alQurthubi, dalam hadis ini dijadikannya 'urf sebagai pertimbangan penetapan hukum Syariat oleh Rasulullah saw ${ }^{21}$.

3. Para ulama dari masa yang berbeda, berhujjah dengan urf dengan memasukkan pertimbangan 'urf dalam ijtihad mereka. Ini sebagai pertanda sahnya penggunaannya, ini posisinya sama dengan ijma`sukuti. Sebagian mereka secara tegas menggunakannya sedang yang lain tidak membantahnya ${ }^{22}$. Lebih lanjut ia menyatakan sesungguhnya 'urf pada hakikatnya berdasarkan pada dalil Syara' yang mu'tabarah, seperti ijma', mashlahah mursalah dan al-dzri'ah. 'Urf yang berdasarkan ijma' antara lain: jual beli secara pesanan, ketentuan tentang penyewaan kamar mandi umum² ${ }^{23}$. Syatibi mendasarkan bahwasan ijma ulama menyatakan bahwa sesungguhnya syariat Islam itu datang untuk memelihara kemaslahatan manusia. Untuk itu wajib memperhatikan tradisi-tradisi mereka karena di dalamnya terwujudnya kemaslahatan tersebut ${ }^{24}$.

\footnotetext{
${ }^{20}$ Muhammad Abu Zahrah, Ushul Figh, h. 273.

${ }^{21}$ Barry, Mashadir al-Ahkam..., h. 146.

${ }^{22}$ Abdul Karim Zaidan, Al-Wajiz fi Ushul..., h. 255.

${ }^{23}$ Abdul Karim Zaidan, Al-Wajiz fi Ushul..., h. 255.

${ }^{24}$ Wahbah al-Zuhaili, Ushul al-Fiqh..., h. 837-838.
}

4. Keberlakuan 'urf dalam kehidupan manusia merupakan sebagai dalil bahwa ia mendatangkan kemaslahatan bagi mereka atau melenyapkan kesulitan. Mashlahah merupakan dalil syar $i$ demikian juga melenyapkan kesulitan adalah tujuan syar' $i$. Ajaran Islam datang dengan mengakomodir kemashlahatan yang telah menjadi urf bangsa Arab pra Islam seperti dalam masalah kafáah dalam perkawinan, ashabiyyah dalam perwalian dan waris, dan kewajiban membayar diyat bagi orang membunuh secara tidak sengaja $(k h a t h a)^{25}$.

\section{'Urf Dalam Pemahaman Fikih Ulama Mujtahidin}

1. Kaedah Ushuliyyah yang terkait dengan pemberlakuan 'Urf

Diterimanya ’urf sebagai salah satu dalil dalam penetapan hukum Islam memberipeluang bagi dinamisasi hukum Islam. Sebab banyak permasalahan yang tidak tertampung dalam metode qiyas, istihsan, mashlahah mursalah dan yang lainnya dapat ditampung oleh 'urf. Di antara kaedah ushuliyah yang terkait dengan pembahasan 'urfantara lain ${ }^{26}$ :

a. Kaedah yang menyatakan bahwa hukum yang dalam pembentukannya oleh mujtahid berdasarkan 'urf, akan berubah jika 'urf itu berubah. Ibnu Qayyim al-Jauziyah (w. 751H) menyatakan, تغير الاحكام بتغير الازمنة (hukum itu berubah karena ada perubahan waktudan tempat). Sebagai contoh ketentuan pemberian nafkah istri dan anak. Ini dapat dengan merujuk kepada adat kebiasaan yang berlaku dalam masyarakat tempat seseorang itu berada 27. Dalam bahasa yang sedikit berbeda, ada ulama yang menyatakan,' la yunkir taghayyur al-ahkam bitaghayyur al-azman'28.

b. Kaedah العادة محكمة (adat kebiasaan itu bisa menjadi hukum)

c. Kaedah استعمال الناس حجة يجب العمل .بما. Kaedah ini

\footnotetext{
${ }^{25}$ Barry, Mashadir al-Ahkam..., h. 147.

${ }^{26}$ Cek lebih lanjut Zuhaili, Ushul al-Figh..., h. 858-863.

${ }^{27}$ Nasrun Haroen, Ushul Fiqh, h. 143.

${ }^{28}$ Wahbah al-Zuhaili, Ushul al-Fiqh..., h. 861.
} 
sama pengertiannya dengan kaedah nomor dua. $^{29}$

d. Kaedah المعروف عرفا كالمشروط شزطا (sesuatu yang baik itu menjadi 'urf, sebagaimana yang disyaratkan itu menjadi syarat). Sesuatu yang telah menjadi 'urf dalam masyarakat, baik berupa perbuatan maupun perkataan adalah untuk pengaturan hidup dan kebutuhan mereka. Apabila mereka berkata atau menulis sesuatu yang dimaksudkan adalah sesuai dengan pengertian yang telah mereka kenal (telah menjadi 'urf di antara mereka). Apabila mereka berbuat sesuatu maka mereka berbuat sesuai dengan kebiasaan yang telah melembaga di kalangan mereka. Dan apabila mereka mendiamkan; tidak memberi ketegasan tentang sesuatu maka yang dimaksudkan adalah sesuatu yang sesuai dengan 'urf mereka. Oleh sebab itu, para fukaha menyatakan: al-ma'ruf 'urfan $k a$ al-masyruth syarthan (sesuatu yang baik itu menjadi urf, sebagaimana yang disyaratkan itu menjadi syarat). Dan sesungguhnya syarat dalam sebuah akad itu dipandang sah jika merupakan keharusan dari akad itu sendiri, telah ditentukan oleh Syara', atau sesuatu yang berlaku dalam 'urfo.

e. Kaedah المعروف بين التجار كالمشروط بينهم (kebiasaan yang berlaku di kalangan pedagang kedudukannya sama dengan berlakunya persyaratan di antara mereka). Kaedah ini semakna dengan kaedah sebelumnya.

f. Kaedah التعيين بالعرف كالتعيين بالنص

g. Kaedah الثابت بالعرف كالثابت بالنص بالنين بالنص (sesuatu yang ditetapkan berdasarkan 'urf sama dengan yang ditetapkan melalui nash) ${ }^{31}$. Ulama yang mensyarah kitab al-Asybah wa al-Nazhair, menyatakan "al-tsabit bi al-'urf tsabit bi al-dalil syar ' $i$ " dan dalam bahasa yang senada Sarakhsi menyatakan, "al-tsabit bi al-'urf tsabit bi an-nash" bahwa permasalahan yang ditetap-

${ }^{29}$ Ali Ahmad al-Nadawi, al-Asybah wa al-Nazhär, (Damaskus: Dar al-Qalam, 1994), h. 65.

${ }^{30}$ Abd al-Wahhab Khallaf, 'Ilmu Ushul..., h. 146-147.

${ }^{31}$ Nasrun Haroen, Ushul Figh, h. 143. kan berdasarkan 'urf merupakan penetapan dengan dalil yang diyakini sebagaimana halnya nash (Alquran dan hadis) ketika tidak ditemukannya nash tentang persoalan tersebut ${ }^{32}$.

h. Fukaha dari kalangan mazhab Hanafi menyatakan, العرف قاض على اللغة (pengertian menurut 'urf ('urf lafzhi) itu yang digunakan dalam memahami suatu istilah) $)^{33}$.

i. Kaedah الحقيقة تترك بدلالة العادة berlaku hanya pada 'urf lafzhi. Artinya yang dipakai adalah pengertian kata tersebut dalam kebiasaan masyarakat bukan maknanya yang hakiki.

j. Kaedah الاشارة المعهودة للأخراس كالبيان باللسان (bahasa isyarat yang diungkapkan oleh orang tuna wicara itu kedudukannya sama dengan penjelasan secara lisan).

k. Kaedah الكتاب كالخطاب berlaku pada `urflafzhi. Kaedah kedua sampai dengan kesebelas ini terkait dengan 'urflafzhi.

1. Kaedah Kنا تعتبر العادة اذا اضطرد ت او غلبت artinya suatu 'urf itu barulah dapat dijadikan landasan hukum jika ia telah menjadi tradisi serta dipraktikkan oleh masyarakat secara umum.

m. Kaedah العبرة للغالب لا للنادر. Kaedah ini dan kaedah kesepuluh menjadi qayyid dari kaedah al-adah muhakkamah. ${ }^{34}$

\section{Pertentangan dalil dalam 'Urf}

Berikut ini bentuk ta arudh terkait dengan masalah `urf:

a. Jika 'urf bertentangan dengan hukum yang bersifat umum yang didasarkan pada dalil yang zhanni.

1) Jika 'urf itu adalah 'urf lafzhi maka ia memahami nash itu berdasarkan pemahaman 'urf tersebut. Seperti dalam memahami makna shalat, nikah, jual beli dan sebagainya.

2) Jika dengan 'urf 'amali, maka ia men-

\footnotetext{
${ }^{32}$ Muhammad Abu Zahrah, Ushul Figh, h. 273.

${ }^{33}$ Zuhaili, Ushul al-Figh..., h. 840.

${ }^{34}$ Ali Ahmad al-Nadawi, al-Asybah wa al-Nazhäir, h. 166.
} 
takhshish dalil zhanni itu ${ }^{35}$. Berikut ini beberapa contoh:

- Membolehkan istishna' berdasarkan urf yang berkembang di masyarakat yang mentakhshish hadis tetang larangan praktik jual beli sesuatu yang belum ada bendanya.

- Di kalangan Hanafiyah dan Malikiyah membolehkan pempersyaratkan sesuatu hal dalam berjual beli. Persyaratan itu haruslah persyaratan yang telah menjadi ‘urf dalam masyarakat tersebut. Ini mentakhshish hadis Nabi yang melarang jual beli bersyarat.

Demikian juga keumuman yang terdapat dalam Q.S. al-Baqarah[2]:233 tentang persusuan yang ditakhshish dengan kebiasaan wanita bangsawan Arab yang tidak menyusui sendiri anak-anak mereka ${ }^{36}$.

b. Jika 'urf yang datang belakangan bertentangan dengan nash yang bersifat umum. Maka berdasarkan kesepakatan para Ushuliyun maka 'urf tersebut tidak boleh mentakhshish nash tersebut ${ }^{37}$.

c. Jika 'urf bertentangan dengan nash yang bersifat khusus. Jika suatu perbuatan itu dilarang oleh syara' karena terdapat kerusakan dan kemudharatan di dalamnya, kemudian terdapat tradisi dalam masyarakat yang menganggap baik larangan tersebut, maka tradisi itu harus ditolak ${ }^{38}$.

d. Jika 'urf bertentangan dengan qiyas, para ulama sepakat mengabaikan qiyas dan mengamalkan 'urf; sekalipun 'urf itu datangnya belakangan. Karena 'urfitu biasanya menjadi dalil berdasarkan kebutuhan padanya dan memelihara kemaslahatan, demikian itu lebih kuat dari qiyas. Inilah yang disebut oleh kalangan Hanafiyah dan Malikiyah dengan istihsan ${ }^{39}$.

\footnotetext{
${ }^{35}$ Zuhaili, Ushul al-Fiqh..., h. 850.

${ }^{36}$ Barry, Mashadir al-Ahkam..., h. 147.

${ }^{37}$ Zuhaili, Ushul al-Figh..., h. 851.

${ }^{38}$ Zuhaili, Ushul al-Fiqh..., h. 852.

${ }^{39}$ Zuhaili, Ushul al-Fiqh..., h. 856.
}

\section{Contoh-contoh Praktek Urf dalam masing- masing mahzab}

1. Fikih Hanafy

a. Dalam akad jual beli seperti standar harga, jual beli rumah yang meliputi bangunannya meskipun tidak disebutkan.

b. Bolehnya jual beli buah yang masih dipohon karena 'urf.

c. Bolehnya mengolah lahan pertanian orang lain tanpa izin jika di daerah tersebut ada kebiasaan bahwa lahan pertanian digarap oleh orang lain, maka pemiliknya bisa meminta bagian.

d. Bolehnya mudharib mengelola harta shahibul mal dalam segala hal menjadi kebiasaan para pedagang.

e. Menyewa rumah meskipun tidak dijelaskan tujuan penggunaaannya

2. Fikih Maliki

a. Bolehnya jual beli barang dengan menunjukkan sampel

b. Pembagian nisbah antara mudharib dan shahibul maal berdasarkan `urfjika terjadi perselisihan

c. Bolehnya jual beli buah yang masih dipohon karena jika sebagian nampak buahnya dan sebagian belum tampak karena seperti semangka terong dan anggur 'urf. ${ }^{40}$

3. Fikih Syafi’

a. Batasan penyimpanan barang yang dianggap pencurian yang wajib potong tangan

b. Akad sewa atas alat transportasi

c. Akad sewa atas ternak

d. Akad istishna ${ }^{41}$

4. Fikih Hanbali: Jual beli mu'athah $^{42}$

\footnotetext{
${ }^{40}$ Zuhaili, Ushul al-Fiqh..., h. 829.

${ }^{41}$ Abd al-Wahhab Khallaf, Mashadir al-Tasyri'..., h. 68.

${ }^{42}$ Abd al-Wahhab Khallaf, Mashadir al-Tasyri '.., h. 67.
} 


\section{Contoh 'Urf yang berlaku}

Berikut adalah akad-akad saat ini yang dapat diterima dengan 'Urf, yaitu:

a. Konsep Aqilah dalam asuransi

b. Jual beli barang elektronik dengan akad garansi

c. Dalam sewa menyewa rumah. Biaya kerusakan yang kecil-kecil yang seharusnya menjadi tanggung jawab pemilik rumah, menjadi tanggung jawab penyewa.

Para ulama sepakat bahwa 'urf shahih dapat dijadikan dasar hujjah. Ulama Malikiyah terkenal dengan pernyataan mereka bahwa amal ulama Madinah dapat dijadikan hujjah, demikian pula ulama Hanafiyah menyatakan bahwa pendapat ulama Kufah dapat dijadikan dasar hujjah. Para ulama telah sepakat bahwa seorang mujtahid dan seorang hakim harus memelihara 'urf shahih yang ada di masyarakat dan menetapkannya sebagai hukum. Para ulama juga menyepakati bahwa 'urf fasid harus dijauhkan dari kaidah-kaidah pengambilan dan penetapan hukum. 'Urf fasid dalam keadaan darurat pada lapangan muamalah tidaklah otomatis membolehkannya. Keadaan darurat tersebut dapat ditoleransi hanya apabila benarbenar darurat dan dalam keadaan sangat dibutuhkan. Imam Syafi'i terkenal dengan qaul qadim dan qaul jadidnya. Ada suatu kejadian tetapi beliau menetapkan hukum yang berbeda pada waktu beliau masih berada di Mekkah (qaul qadim) dengan setelah beliau berada di Mesir (qaul jadid). Hal ini menunjukkan bahwa ketiga mazhab itu berhujjah dengan 'urf. Tentu saja 'urffasid tidak mereka jadikan sebagai dasar hujjah ${ }^{43}$.

Abdul Wahab Khallaf berpandangan bahwa suatu hukum yang bersandar pada 'urfakan fleksibel terhadap waktu dan tempat, karena Islam memberikan prinsip sebagai berikut: "Suatu ketetapan hukum (fatwa) dapat berubah disebabkan berubahnya waktu, tempat, dan situasi (kondisi)". Dengan demikian, memperhatikan

${ }^{43}$ Abd al-Wahhab Khallaf, Mashadir al-Tasyri '.., h. 67. waktu dan tempat masyarakat yang akan diberi beban hukum sangat penting. Prinsip yang sama dikemukakan dalam kaidah sebagai berikut:

"Tidak dapat diingkari adanya perubahan karena berubahnya waktu/zaman."

Dari prinsip ini, seseorang dapat menetapkan hukum atau melakukan perubahan sesuai dengan perubahan waktu (zaman). Ibnu Qayyim mengemukakan bahwa suatu ketentuan hukum yang ditetapkan oleh seorang mujtahid mungkin saja mengalami perubahan karena perubahan waktu, tempat keadaan, dan adat. Jumhur ulama tidak membolehkan 'urf khash. Sedangkan sebagian ulama Hanafiyyah dan Syafi iyyah membolehkannya, dan inilah pendapat yang shahih karena kalau dalam sebuah negeri terdapat urftertentu maka akad dan muamalah yang terjadi padanya akan mengikuti 'urftersebut.

\section{Penutup}

Karakteristik hukum Islam adalah syumul (universal) dan waqi iyah (kontekstual) karena dalam sejarah perkembangan (penetapan)ya sangat memperhatikan tradisi, kondisi (sosio kultural), dan tempat masyarakat sebagai objek (khitab), dan sekaligus subjek (pelaku, pelaksana) hukum. Perjalanan selanjutnya, para Imam Mujtahid dalam menerapkan atau menetapkan suatu ketentuan hukum ( $f$ ikih) juga tidak mengesampingkan perhatiannya terhadap tradisi, kondisi, dan kultural setempat. Tradisi, kondisi (kultur sosial), dan tempat merupakan faktor-faktor yang tidak dapat dipisahkan dari manusia (masyarakat). Karena itu, perhatian dan respons terhadap tiga unsur tersebut merupakan keniscayaan. Tujuan utama syariat Islam (termasuk didalamnya aspek hukum) untuk kemaslahatan manusia-sebagaimana dikemukakan al-Syatibi akan terealisir dengan konsep tersebut. Pada gilirannya syariat (hukum) Islam dapat akrab, membumi, dan diterima di tengah-tengah kehidupan masyarakat yang plural, tanpa harus meninggalkan prinsip-prinsip dasarnya. Sehingga dengan metode al- urf ini, sangat diharapkan berbagai macam problematika 
kehidupan dapat dipecahkan dengan metode ushul al-figh, salah satunya al- 'urf, yang mana 'urf dapat memberikan penjelasan lebih rinci tanpa melanggar Alquran dan sunah.

\section{Pustaka Acuan}

Ba'labaki, Ruhi, al-Maurid, Qamus 'Arabi Ingglizi, Beirut: Dar al-Ilmi lilmalayin, 1993.

Barriy, Zakariya al-, Mashadir al-Ahkam alIslamiyah, Kairo: Dar al-Ittihad al-Arabiy, 1975.

Haroen, Nasrun, Ushul Fiqh 1, Jakarta: Logos, 1997, Cet. ke-2.

Hasaballah, 'Ali, Ushulal-Tasyri' al-Islami, Kairo: Dar al-Fikr al-'Arabi,1998.

Khallaf, Abd al-Wahhab, Mashadirat-Tasyri alIslami fi ma la Nashsha Fiha, Beirut: Dar alQalam, 1972.

Khallaf, Abd al-Wahhab, Ushul Figh, Beirut: Dar al-Fikr, 1986, Cet. ke-20.

Murtadho, Moh., Ilmu Falak Praktis, Malang: UIN Malang, 2008, Cet. ke-1.
Nadawi, Ali Ahmad al-, al-Asybah wa alNazhair, Damaskus: Dar al-Qalam, 1994.

Nasution, Lahmuddin, Pembaharuan Hukum Islam dalam Mazhab Syafi'i, Jakarta: PT Remaja Rosda Karya, 2001, Cet. ke-1.

Pusat Bahasa Departeman Pendidikan Nasional, Kamus Besar Bahasa Indonesia, Jakarta: Balai Pustaka, 2008.

Syarifuddin, Amir, Ushul Fiqh Jilid 2, Jakarta: Logos, 2001, Cet. ke-2.

Syathibi, al-Muwafaqat fi Ushul al-Syariah, Beirut: Dar al-Ma rifah, 1994.

Zahrah, al-Imam Muhammad Abu, Ushul alFiqh, T.tp: Dar al-Fikr al-`Arabi, 1958.

Zaidan, Abd al-Karim, Al-Wajiz fi Ushulal-Fiqh, Beirut: Muassasah al-Risalah, 1986.

Zein, Satria Effendi M, Ushul Figh, Jakarta: Prenada Media, 2005, Cet. ke-1.

Zuhaili, Wahbah, Ushul al-Figh al-Islami Juz II, Beirut: Dar al-Fikr, 2001. 